\title{
A comparison of faecal analysis with backtracking to determine the diet composition and species preference of the black rhinoceros (Diceros bicornis minor)
}

\author{
Ruud J. van Lieverloo • Bjorn F. Schuiling • \\ Willem F. de Boer • Peter C. Lent • \\ Christine B. de Jong • Derek Brown • Herbert H. T. Prins
}

Received: 9 December 2008 /Revised: 15 March 2009/Accepted: 20 March 2009/Published online: 8 April 2009

(C) The Author(s) 2009. This article is published with open access at Springerlink.com

\begin{abstract}
The diet of black rhinoceros (Diceros bicornis minor) was studied using backtracking and faecal analysis in South Africa. Both methods yielded different results, with a large bias for dominant species. Results of backtracking showed that the rhinos browsed on 80 plant species. Grasses comprised $4.5 \%$ of the diet in the faecal analysis, but were not recorded during the backtracking. The backtracking method, along with a measure of forage availability, was used to identify two groups of plant species, those species taken in a higher proportion than available in the field and those taken in a lower proportion. Chemical analyses showed that these two species groups were similar in in vitro digestibility, macro-elements and fibre constituents. Mean bite size and species contribution to the diet were not correlated with any of the forage quality parameters, indicating that rhinos were not maximising nutrient intake or minimising fibre intake of these consumed plant species.
\end{abstract}

Keywords Diet quality · Preference - Species composition . Grass · Browse

Communicated by W. Lutz

R. J. van Lieverloo • B. F. Schuiling • W. F. de Boer $(\bowtie) \cdot$

C. B. de Jong $\cdot$ H. H. T. Prins

Resource Ecology Group, Wageningen University,

Droevendaalsesteeg 3a,

6708 PB Wageningen, The Netherlands

e-mail: fred.deboer@wur.nl

P. C. Lent $\cdot$ D. Brown

University of Fort Hare, Faculty of Science and Agriculture,

Private Bag x1314,

Alice, Republic of South Africa

\section{Introduction}

Previous studies of black rhinoceros (Diceros bicornis minor) diet have largely depended upon direct observation or backtracking techniques (Goddard, 1968; Schenkel and Schenkel-Hullinger 1969; Joubert and Eloff 1971; Mukinya 1977; Loutit et al. 1987; Emslie and Adcock 1994; Oloo et al. 1994; Atkinson 1995; Pole 1995; Muya and Oguge 2000; Ausland et al. 2002; Brown et al. 2003; Winkel 2004; Ganqa et al. 2005). Microhistological analysis of faeces (Stewart, 1967; de Boer et al. 2000; de Jong et al. 2004) has rarely been attempted, and comparisons of both methods have only been reported previously by Hall-Martin et al. (1982). However, the latter study only identified broad categories in their faecal samples: woody plants, succulents and grasses. Hence, the first objective of this study was to compare these two methods, backtracking and microhistological analysis, and determine the difference in the estimated diet compositions at species level for black rhino.

Our second objective was to test the hypothesis that rhinos select the plants they browse following the predictions derived from the optimal foraging theory (Lacher et al. 1981; Cooper et al. 1988; Belovski 1997). Optimal foraging models are based on the assumption that individuals choose foods that convey the maximum net benefit. For herbivores, this could mean that diet selection is determined by maximising nutrients (e.g. $\mathrm{N}$ or $\mathrm{P}$ content; Owen-Smith and Novellie 1982) or minimising fibre content (Belovski 1997; Ganqa and Scogings 2007). This hypothesis was tested by assessing the botanical composition of the black rhino diet in relation to forage abundance and quality. For instance, Ganqa et al. (2005) reported that crude protein was positively correlated with woody species preference of black rhino. In order to determine the browse 
quality, chemical analyses were carried out on the most important plant species in the rhino's diet. The prediction that species that were consumed in a higher proportion than available in the field have higher amounts of nutrients (macro-elements), lower amounts of fibres (neutral detergent fibre, NDF) and higher digestibility values than those species that were consumed in a lower proportion than available in the field was tested in this study.

\section{Materials and methods}

Study area

The research was conducted in the Great Fish River Reserve (GFRR) in South Africa (33 $09^{\prime} \mathrm{S}$ and $26^{\circ} 49^{\prime} \mathrm{E}$ ). The reserve lies within the thicket biome of the Eastern Cape Province (Cowling et al. 2005) and is considered to be a good habitat for the black rhinoceros (Lent and Fike 2003), as evidenced by the rapid increase of the population (Heilmann et al. 2006). The fieldwork was, for logistical reasons, concentrated on the western side of the Great Fish River, the area with the highest rhino density. The vegetation is dominated by dense clumps of thorny and succulent shrubs (Lent and Fike 2003). Major vegetation types include bush clump savanna, dry forest, medium Portulacaria thicket, riverine Acacia thicket, short Euphorbia thicket and tall Euphorbia thicket (Brown et al. 2003, adapted from Evans et al. 1997).

\section{Diet assessment: backtracking}

The diet of individual rhinos can be determined by tracking backwards and locating distinctive bite marks (a scissorlike cut stump) left by feeding animals (Muya and Oguge 2000). A bite mark was identified as any isolated severed shoot or branch that was bitten off. When numerous contiguous shoots or branches were bitten off at the same level, all shoots occurring within a circle of $10-\mathrm{cm}$ diameter were recorded as one bite, based on own observations of rhino bite sizes. Together with an experienced rhino tracker, searching for fresh rhino tracks was started early in the morning by car using only tracks that were not older than a few hours to ensure that all fresh bites belonged to the same individual. Fresh bite marks, spoor near plants, leaves on the ground and discolouration of stems were used as indications of recent rhino browse events, enabling distinction of bites from other browser species. Each track was assigned a unique number and date, rhino ID (if possible), and vegetation type was noted. Backtracking was carried out only in two periods, both in the wet season, from February to March 2004 (21 backtracks or $57 \%$ of all 5,479 recorded bites) and from April to May 2004 (13 backtracks, $43 \%$ of all bites). For every bite mark the species, height of the bite mark in four classes $(0-0.5,0.51-1,1.1-1.5$, and $>1.5 \mathrm{~m})$ and diameter of each twig (in millimetres) were recorded. In total, 34 backtracks were carried out, distributed over the bush clump savanna (eight backtracks, comprising 19\% of all recorded bites), dry forest (three, 12\%), medium Portulacaria thicket (nine, 32\%), riverine Acacia thicket (nine, 32\%), short Euphorbia thicket (two, 2\%) and tall Euphorbia thicket (three, 4\%).

We calculated the amount of total biomass consumed per bite using estimates based on regressions between twig diameters of each cutoff branch and the dry mass of branches (calculated from 60 twigs per species) collected in the wet season between March and May 2004. This we did for ten species, namely Azima tetracantha, Coddia rudis, Euclea undulata, Grewia occidentalis, Grewia robusta, Jatropha capensis, Lycium ferocissimum, Plumbago auriculata, Rhigozum obovatum and Schotia afra. For the other woody species, a single curve was derived from the mean values of the above ten species. Six of these regression equations are shown in Fig. 1, calculated using the curve estimation option in SPSS. Explained variances were very high $\left(R^{2}, 85-95 \%\right)$, so we feel confident using these regressions. For each backtrack, the total biomass was calculated by addition of the estimated amount of biomass per bite, calculated from the latter regression equations. If one bite comprised several twigs, the total bite biomass was calculated by summing the biomass of each of the twigs.

Seventeen species that in total comprised $85 \%$ of diet intake were termed 'principal species'. Among these, preferred (positively selected: consumed in a higher proportion than available) and rejected species (negatively selected: consumed in a lower proportion than available) were determined using the ratio between browse availability and diet composition. Hence, we concentrated our analysis of those species which were relatively abundant in the rhino's diet, omitting the species that were not consumed or consumed in relatively low quantities.

Availability data were obtained from density estimates of woody browse species located within $50 \mathrm{~cm}$ of browsed plants on backtracks of D. Brown in the wet season of 2002 at rhino browse height (Brown et al. 2003). For this purpose, data were collected from a total of 3,549 points on 92 backtracks randomly distributed over the six vegetation types. These 3,549 points are regarded as a random sample of the vegetation composition in the study area. These availability data were collected in the same areas but 2 years earlier. We assumed that the data would still be representative for forage availability because they were derived from counts of individual whole shrubs and trees. 
Fig. 1 Correlation between twig diameter and dry mass for six well-utilised woody browse species in the thicket vegetation of the Great Fish River Reserve, South Africa

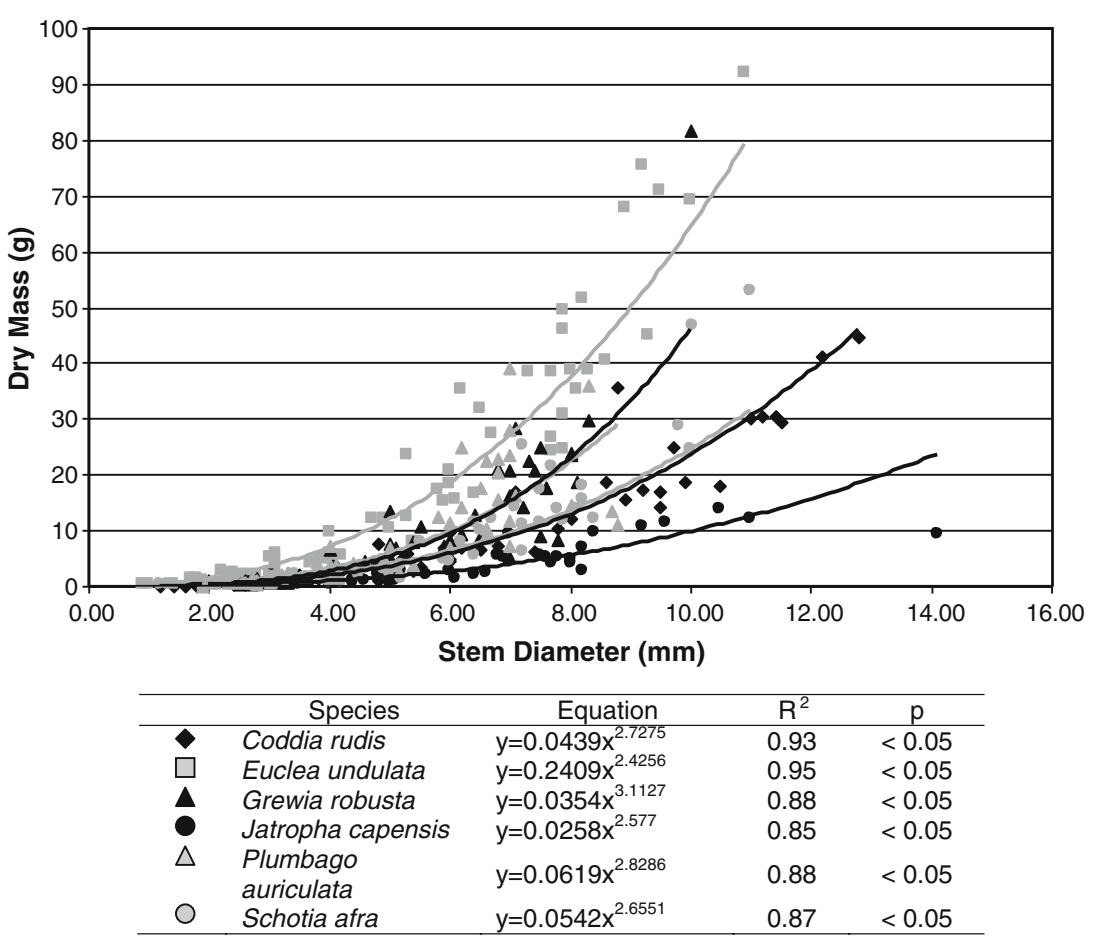

Diet assessment: microhistological faecal analysis

Microhistological examination of herbivore faeces provides an estimate of the ingested biomass per plant taxon based on the assumption that the ratio between the surface area and dry matter of leaves is more or less constant in different plant species (Stewart 1967; Sparks and Malechek 1968; Cid and Brizuela 1990; Bartolome et al. 1995). This allows for the comparison of the proportion of a species in the diet and the available biomass. To this end, epidermal fragments of ingested plants in the faeces were compared to photomicrographs of epidermal fragments on reference slides. This is possible because the plant cuticle, an indigestible layer covering the epidermis, bears a specific pattern of underlying epidermal cells and hairs along with structures of its own (Stace 1965; de Jong et al. 2004).

Samples of every fresh dropping or dung heap found during backtracking were collected in the wet season of 2004, from February to May. All fresh droppings found in a similar vegetation type were pooled and mixed thoroughly, yielding two mixed samples from the bush clump savanna, one from the dry forest, two from the medium Portulacaria thicket, two from the riverine Acacia thicket, and one from the tall Euphorbia thicket. Samples were stored in a freezer.

Mixed samples were then sterilised through repeated boiling and stored in a 70\% ethanol solution. A 5-g subsample of each sample was washed with water in a Waring Blender (Waring Products, 38b140, Torrington, USA), strained over a $0.1-\mathrm{mm}$ plankton sieve and stored in a $70 \%$ ethanol solution.
Ten random grab samples of the faecal sample were examined by light microscopy, and at least 100 cuticular or epidermal fragments were identified by comparing them with microscopic photographs of epidermal material. These were then measured using a grid of $0.01-\mathrm{mm}^{2}$ squares in the microscope eyepiece (De Jong et al. 1995; 2004) to find ingested plant species that comprised at least $5 \%$ of the total diet (Stewart 1967). Fragments smaller than $0.01 \mathrm{~mm}^{2}$ were ignored, as identification of these is not conclusive for all species (Martin 1955). The relative abundance of each species was calculated as a percentage of the total area of the fragments measured (Stewart 1967; Sparks and Malechek 1968; Putman 1984; Cid and Brizuela 1990; Alipayo et al. 1992, Homolka and Heroldová 1992). A reference collection was compiled of epidermal samples from 52 plant species. These samples were produced by soaking pieces of twig, leaf and, where available, flowers and fruits in household bleach $(5 \%$ sodium hypochlorite, $\mathrm{NaClO}$ ) overnight to facilitate the removal of the epidermis layer. The resulting fragments were then washed in water, and sections of the epidermis were stripped off and mounted in glycerol. Microscopic photographs of these slides were then used to identify the cuticle fragments in the rhino faeces using morphological characteristics such as cell walls, stomata and hairs.

Browse quality

Browse quality was hypothesised to be higher for preferred species and lower for rejected species. We tested this 
hypotheses with a forage quality analysis, comparing the five most preferred species, the four most rejected species and the eight other 'principal forage' species (that were neither preferred nor rejected, but consumed in a similar proportion as available, classified as "indifferent"). In total, these 17 species comprised $85 \%$ of the rhino diet (Table 1). This analysis was only carried out for the backtrack data, as we were unable to identify each fragment in the faecal analysis to species level. Due to logistical reasons, we were unable to determine the browse quality of those plants that were available but were never recorded in the diet. These truly rejected species might be of an even lower quality than the species analysed here, but we were unable to check this assumption.

Browse quality for each of the above species was determined by sampling 60 unbrowsed branches collected during the wet season on 2004, from February to May, like the branches eaten by black rhino. A maximum of five twigs were selected from any one plant. Data on browsing height and branch diameter of the 60 twigs were obtained from the backtracking results and were used when sampling to simulate black rhino intake and to collect representative samples at equal height and similar diameter, as twigs taken by black rhino. Leaves and twigs were analysed separately. After drying at $60^{\circ} \mathrm{C}$ for a minimum of $48 \mathrm{~h}$, the samples were ground (Cullati grinder TK 3237, Kinematica AG, Germany) and stored.

Samples were analysed for in vitro digestibility, macroelements (N, P, Na, Ca, K and $\mathrm{Mg}$ ) and fibre constituents as NDF. Water content and twig/leaf ratios were also recorded. Total nitrogen, phosphorus, sodium, calcium, potassium and magnesium were measured after a Kjeldahl destruction (Bradstreet 1954). Total nitrogen and phosphorus concentrations were measured colourimetrically (Ewing 1997) using a continuous-flow analyzer (SAN Plus Segmented Flow Analyser Skalar SA-4000, Skalar UK, York, UK). Crude protein content was calculated from the nitrogen content by multiplication of 6.25. Total sodium, calcium, potassium and magnesium concentrations were measured using an atomic absorption spectrophotometer (Varian Spectra AA-600, Varian, Palo Alto, USA). Digestibility was determined according to the method of Tilly and Terry (1963). This method imitates the digestion process of ruminants. The samples were incubated with cattle rumen liquid followed by incubation with a pepsin/ $\mathrm{HCl}$ solution. NDF was determined by boiling the samples in neutral detergent reagent which dissolves the cell contents, leaving the NDF. NDF residue was expressed as a percentage (without subtracting residual ash) in per cent of dry matter (Udén et al. 2005).

\section{Statistical analyses}

The results of the faecal analysis were compared to backtrack results using the Spearman's rank coefficient
(Zar 1984). Assuming that the systematic bias of the faecal analysis is smaller, we calculated the correlation between the two methods to study the bias in the backtracking method. To determine the difference between two periods in the wet season and between the faecal analysis and the backtracking results, a chi-square analysis was also carried out, followed by an analysis of the residual values (Siegel and Castellan 1988). The differences between the preferred and rejected species were assessed using Mann-Whitney $U$ tests (when the data were not normally distributed) or independent sample $t$ tests (when data followed a normal distribution; Zar 1984) in SPSS. These tests were calculated for twigs and leaves separately. The stem succulent Euphorbia bothae was included only in the analysis for twigs.

\section{Results}

Diet assessment: backtracking

On 34 backtracks, we identified 80 species that were consumed by black rhino. Five species only, G. robusta, $C$. rudis, $P$. auriculata, E. undulata and $A$. tetracantha (Table 1), accounted for $68.8 \%$ of the diet in terms of biomass intake.

Most browsed twigs $(71.0 \%)$ were recorded in the 0 3.5-mm diameter class; $68.8 \%$ of the bites was taken from the first height class $(0-0.5 \mathrm{~m})$ and only $4.7 \%$ in the last height class $(\geq 1.5 \mathrm{~m})$. These percentages varied among species. For example, on two backtracks, one in bush clump savanna and another in riverine Acacia thicket, almost all Acacia karroo plants with heights under $50 \mathrm{~cm}$ were browsed. They accounted for $86.0 \%$ of all bites $(N=$ 114) of $A$. karroo plants ingested during these two backtracks, whilst taller individuals remained largely untouched.

At first sight, the diet composition in the two sample periods in the wet season as determined by backtracking were highly correlated (Fig 2; Spearman $r=0.552 ; P<$ $0.001 ; N=42$ ), but this is mainly caused by the large number of species that are clustered around the origin, with a contribution to the diet $<5 \%$. Those species that were dominant in the diet as established with this method show large differences. If the rarer species are omitted from the analysis and one selects only those six species with a larger contribution to the diet than 5\% (contributing, respectively, in total $69.1 \%$ and $80.9 \%$ to the diet in, respectively, February-March and April-May), a negative relationship is obtained between the different periods, although this was not significant (Spearman $r=-0.029 ; P>0.05 ; N=6$ ). However, when the number of bites of those six species is compared between the two periods in a chi-square analysis, a significant difference is found in species composition between the two periods $\left(\chi^{2}=5,431, d f=5, P<0.001\right)$. 
Table 1 Black rhino diet composition comparing backtracking and faecal analysis methods
${ }^{\text {a }}$ Listed in order of importance based on backtracking results

${ }^{\mathrm{b}}$ Species are lumped by genus for Asparagus spp., Euphorbia spp., Grewia spp., Rhus spp., or by family for Leguminosae (A. karroo and S. afra), and Justicia protracta is included with Acanthaceae spp. in the faecal analyis

\begin{tabular}{|c|c|c|c|c|}
\hline & & \multicolumn{2}{|l|}{ Backtracks } & \multirow{2}{*}{$\frac{\text { Faecal analysis }}{\text { Grid cells (\%) }}$} \\
\hline \multicolumn{2}{|c|}{ Plant species ${ }^{\mathrm{a}}$} & Biomass $(\%)$ & Bites (\%) & \\
\hline 1 & Grewia robusta & 16.3 & 16.7 & $-{ }^{\mathrm{b}}$ \\
\hline 2 & Coddia rudis & 15.6 & 8.5 & 2.9 \\
\hline 3 & Plumbago auriculata & 13.0 & 13.5 & 8.8 \\
\hline 4 & Euclea undulata & 12.4 & 4.8 & 10.2 \\
\hline 5 & Azima tetracantha & 11.5 & 9.0 & 7.6 \\
\hline 6 & Jatropha capensis & 4.6 & 8.9 & 1.9 \\
\hline 7 & Lycium ferocissimum & 3.5 & 7.7 & 1.0 \\
\hline 8 & Portulacaria afra & 2.0 & 0.5 & 0.7 \\
\hline 9 & Phylobolus spp. & 2.0 & 1.9 & 0.0 \\
\hline 10 & Acacia karroo & 1.5 & 2.5 & $-{ }^{\mathrm{b}}$ \\
\hline 11 & Justicia protracta & 1.4 & 2.7 & $-{ }^{\mathrm{b}}$ \\
\hline 12 & Euphorbia bothae & 1.3 & 2.0 & $-{ }^{\mathrm{b}}$ \\
\hline 13 & Carissa haematocarpa & 1.1 & 0.7 & 0.5 \\
\hline 14 & Grewia occidentalis & 1.1 & 3.1 & $\mathrm{~b}$ \\
\hline 15 & Maytenus capitata & 1.0 & 1.2 & 1.6 \\
\hline 16 & Verbesina encelioides & 1.0 & 1.8 & 0.0 \\
\hline 17 & Euphorbia tree spp. & 1.0 & 1.5 & $-{ }^{\mathrm{b}}$ \\
\hline 18 & Brachylaena ilicifolia & 0.9 & 0.8 & 0.6 \\
\hline 19 & Asteraceae spp. & 0.9 & 1.2 & 0.0 \\
\hline 20 & Rhus longispina & 0.9 & 1.0 & $-{ }^{\mathrm{b}}$ \\
\hline 21 & Schotia afra & 0.8 & 0.9 & $-{ }^{\mathrm{b}}$ \\
\hline 22 & Phyllanthus verrucosus & 0.6 & 0.7 & 0.3 \\
\hline 23 & Rhigozum obovatum & 0.5 & 0.8 & 0.2 \\
\hline 24 & Ehretia rigida & 0.4 & 0.2 & 0.0 \\
\hline \multirow[t]{13}{*}{25} & Asparagus suaveolens & 0.4 & 1.3 & $-{ }^{\mathrm{b}}$ \\
\hline & Acanthaceae spp. & & & 0.4 \\
\hline & Asparagus spp. & & & 18.4 \\
\hline & Euphorbia spp. & & & 9.3 \\
\hline & Grewia spp. & & & 7.8 \\
\hline & Leguminosae spp. & & & 4.0 \\
\hline & Rhus spp. & & & 1.4 \\
\hline & Grasses & & & 4.5 \\
\hline & Unidentified species & 4.4 & 6.3 & 18.1 \\
\hline & Total $(\%)$ & 100 & 100 & 100 \\
\hline & Total biomass (g) & 33,696 & & \\
\hline & Total bites $(N)$ & & 5,479 & \\
\hline & Total identified grid cells $(N)$ & & & 7,332 \\
\hline
\end{tabular}

Indeed, A. tetracantha, Euphorbia spp. and Grewia spp. were much more important during February and March than a few months later, whereas C. rudis, E. undulata and $J$. capensis ranked much higher in April-May than in the months immediately prior to this period.

Diet assessment: microhistological faeces analysis

Because the two methods of estimating diets are different, we compared diet composition results obtained by faecal analysis with those resulting from the backtracking. Although a positive correlation was found between the percentages of the different species in the diet as assessed by backtracking and faecal analysis (Fig. 3; Spearman $r=0.547$; $P<0.001 ; N=42$ species), this is mainly caused by the large number of species $(N=34)$ that contribute $<5 \%$ to the diet in both methods. Notable differences were recorded for the more important species, those species that contributed more than $5 \%$ in one of the two methods $(N=8)$, responsible for, in total, $80.7 \%$ of the diet for the faecal analysis and $76.2 \%$ for 


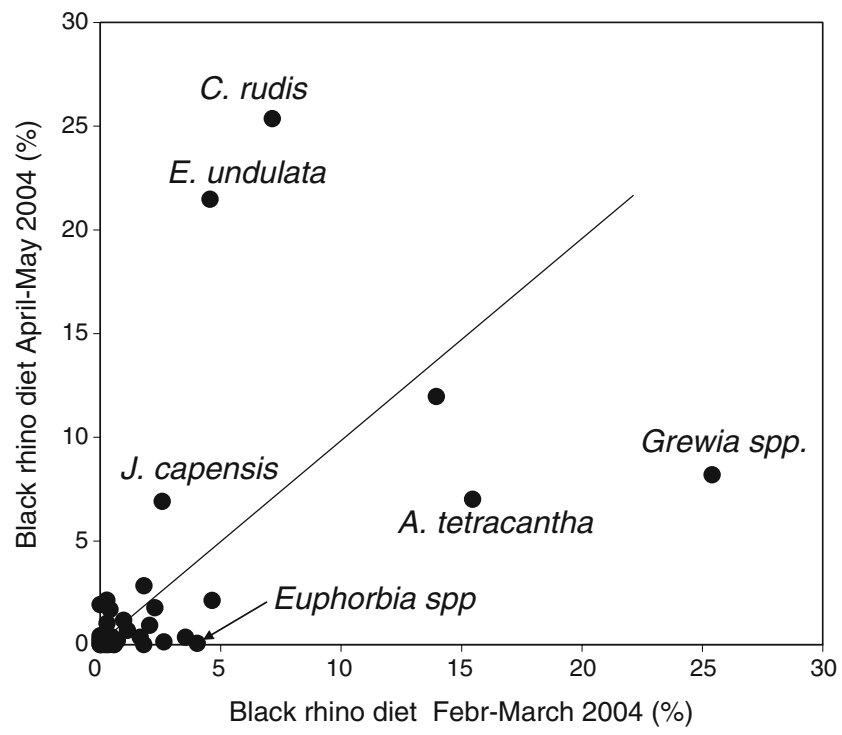

Fig. 2 Comparison of the diet composition (\%) of the black rhino in the Great Fish River Reserve in two periods in 2004, as calculated from backtracking data and biomass-diameter regression analysis. The straight line depicts the expected 1:1 relationship

the backtracks. In comparison to faecal analyses, C. rudis and Grewia spp. are overestimated in the backtracking, whereas Asparagus spp., Euphorbia spp. and grasses are underestimated. There is even a negative relationship now for these eight species when the data of two methods are used in a correlation (Spearman $r=-0.714 ; P<0.05$ ). The difference in species composition is confirmed by a chisquare analysis $\left(\chi^{2}=3,116, d f=7, P<0.001\right)$, and only $E$. undulata was detected in similar proportions by both methods, the other seven species significantly detected more by one of the two methods (chi-square residual analysis; $P<0.05$ ).

Browse quality

We did not find any significant differences in the chemical composition of the preferred and rejected species $(t$ tests or Mann-Whitney $U$ tests; Table 2). Moreover, no significant correlation could be found between the contribution any given principal species made to the diet (whether expressed in biomass or as number of bites) and any of its forage quality parameters.

Mean bite size was calculated from the ratio between the percentage bites and the percentage biomass (Table 1). Mean bit sizes on the different forage species was also not significantly correlated with any of the forage quality indicators.

\section{Discussion}

In this study, we were able to assess the bias of backtracking as compared to faecal analysis when applied to black rhino feeding choices and showed that forage quality parameters were uncorrelated with rhino diet composition.

Diet composition

Black rhinoceros are known to utilise a wide variety of plant species (Hall-Martin et al. 1982; Oloo et al. 1994), but invariably a few species are most important in terms of biomass eaten. In the GFRR, the total number of different consumed plant species was 80 in 34 backtracks. In an earlier study in the GFRR, Ausland and Sveipe (2000) found 45 species in 22 backtracks in the same wet season months in 2000. The diet of black rhino in our study was dominated by five species only, namely $G$. robusta, $C$. rudis, $P$. auriculata, E. undulata and A. tetracantha, which together comprised $68.8 \%$ in terms of total ingested biomass, contributing each between $11.5 \%$ and $16.3 \%$ (Table 1). This result is similar to that of Ausland and Sveipe (2000) who found in the same reserve that five species constituted more than $68 \%$ biomass of the total diet; four species were the same as the ones we found, namely G. robusta, E. undulata, P. auriculata and C. rudis, but they reported $J$. capensis to belong to the dominant dietary species. In our study, this species was of less relevance. In another study in the reserve, a slightly different list of dominant species was reported, namely, again, G. robusta, E. undulata, J. capensis, but then E. bothae and A. tetracantha were included in the dominant species list (Ausland et al. 2002). They, but also Ganqa et al. (2005), reported E. bothae to be a dominant part of the black rhino's diet in the wet season and found a high preference for this species too, similar to Pole's (1995) findings. Because this species occurs almost entirely in the short Euphorbia thicket vegetation type only, we believe that their results apply principally to this vegetation type which is only found in a restricted area and is relatively uncommon on the GFRR. Neither publication described the vegetation type(s) in which their backtracks were situated. The preference for Grewia spp. has also been reported in other studies (Hall-Martin et al. 1982; Emslie and Adcock 1994, Muya and Oguge 2000), but although other studies (Emslie and Adcock 1994; Joubert and Eloff 1971; Mukinya 1977) reported a preference for Acacia spp., this was not observed in the GFRR.

It was noted that the succulent $P$. afra, even in medium Portulacaria thicket where it is the dominant species, comprised only $6 \%$ of the diet based on the number of bites, although it has been generally assumed to be an important browse species for black rhino (Maddock et al. 1995).

The diet of the black rhino in the two time periods of the wet season (February to March versus April to May) in our study was dissimilar for the dominant species that comprised the bulk of the diet. Our study also found a decrease 
Table 2 Chemical composition of 17 principal browse species

\begin{tabular}{|c|c|c|c|c|c|c|c|c|c|c|c|c|}
\hline Preference category & Sample & $\mathrm{T} / \mathrm{L}$ ratio & $\%$ Water & $\% \mathrm{OM}$ & $\%$ dig & $\% \mathrm{NDF}$ & $\% \mathrm{~N}$ & $\% \mathrm{P}$ & $\% \mathrm{~K}$ & $\% \mathrm{Ca}$ & $\% \mathrm{Mg}$ & $\% \mathrm{Na}$ \\
\hline & Leaves & & & & & & & & & & & \\
\hline Indifferent & Acacia karroo & 1.3 & 49.9 & 92.7 & 53 & 28.2 & 2.9 & 0.16 & 0.9 & 1.4 & 0.36 & 0.10 \\
\hline Indifferent & Euclea undulata & 0.5 & 40.6 & 93.7 & 21 & 45.4 & 0.9 & 0.07 & 0.9 & 1.5 & 0.38 & 0.02 \\
\hline Indifferent & Grewia occidentalis & 3.8 & 54.1 & 87.6 & 61 & 36.7 & 3.4 & 0.20 & 2.6 & 2.1 & 0.17 & 0.05 \\
\hline Indifferent & Justicia protracta & 0.7 & 72.8 & n.a. & 80 & 30.2 & 3.8 & 0.40 & 3.0 & 0.4 & 0.82 & 0.06 \\
\hline Indifferent & Lycium ferocissimum & 5.0 & 86.4 & 78.0 & 73 & 24.7 & 4.2 & 0.33 & 3.5 & 1.5 & 0.50 & 0.07 \\
\hline Indifferent & Phylobolus spp. & 2.7 & 88.0 & 83.2 & 76 & 26.0 & 2.6 & 0.18 & 1.5 & 3.2 & 0.60 & 0.29 \\
\hline Indifferent & Ptaeroxylon obliquum & 5.8 & 60.7 & 92.3 & 61 & 27.6 & 3.3 & 0.27 & 1.6 & 1.5 & 0.21 & 0.02 \\
\hline Indifferent & Rhigozum obovatum & 2.2 & 49.0 & 92.9 & 58 & 21.4 & 2.1 & 0.35 & 1.5 & 1.1 & 0.22 & 0.08 \\
\hline Preferred & Azima tetracantha & 0.8 & 60.5 & 77.0 & 64 & 15.2 & 1.9 & 0.10 & 1.9 & 0.4 & 0.35 & 0.17 \\
\hline Preferred & Coddia rudis & 3.5 & 62.1 & 91.3 & 58 & 32.0 & 1.7 & 0.14 & 1.9 & 1.3 & 0.27 & 0.16 \\
\hline Preferred & Grewia robusta & 3.0 & 44.7 & 91.3 & 42 & 35.7 & 2.5 & 0.13 & 1.5 & 1.4 & 0.23 & 0.03 \\
\hline Preferred & Jatropha capensis & 0.9 & 67.3 & 92.2 & 60 & 33.1 & 2.1 & 0.21 & 1.6 & 1.0 & 0.26 & 0.12 \\
\hline Preferred & Plumbago auriculata & 1.6 & 61.2 & 87.2 & 41 & 23.5 & 2.8 & 0.18 & 2.4 & 1.4 & 0.72 & 0.16 \\
\hline Rejected & Ehretia rigida & 4.1 & 66.2 & 86.5 & 48 & 34.5 & 3.3 & 0.20 & 3.4 & 1.6 & 0.45 & 0.12 \\
\hline Rejected & Phyllanthus verrucosus & 3.8 & 46.9 & 92.8 & 76 & 16.1 & 2.2 & 0.26 & 1.2 & 1.2 & 0.25 & 0.06 \\
\hline Rejected & Portulacaria afra & 0.9 & 73.9 & 88.8 & 55 & 30.8 & 0.9 & 0.08 & 2.0 & 0.7 & 0.75 & 0.43 \\
\hline Indifferent & mean & 2.8 & 62.7 & 88.6 & 60 & 30.0 & 2.9 & 0.25 & 1.9 & 1.6 & 0.41 & 0.09 \\
\hline Preferred & mean & 2.0 & 59.2 & 87.8 & 53 & 27.9 & 2.2 & 0.15 & 1.9 & 1.1 & 0.37 & 0.13 \\
\hline \multirow[t]{2}{*}{ Rejected } & mean & 2.9 & 62.3 & 89.4 & 60 & 27.1 & 2.1 & 0.18 & 2.2 & 1.2 & 0.48 & 0.20 \\
\hline & Twigs & & & & & & & & & & & \\
\hline Indifferent & Acacia karroo & & 42.2 & 95.0 & 31 & 50.4 & 1.0 & 0.10 & 0.8 & 0.8 & 0.20 & 0.06 \\
\hline Indifferent & Euclea undulata & & 31.6 & 95.1 & 23 & 52.0 & 0.9 & 0.07 & 0.9 & 1.3 & 0.36 & 0.02 \\
\hline Indifferent & Euphorbia bothae & & n.a. & 87.2 & 75 & 22.5 & 1.3 & 0.42 & 2.7 & 1.2 & 0.39 & 0.41 \\
\hline Indifferent & Grewia occidentalis & & 54.3 & 90.4 & 30 & 49.0 & 1.2 & 0.17 & 1.6 & 1.9 & 0.15 & 0.02 \\
\hline Indifferent & Justicia protracta & & 77.1 & n.a. & 55 & 45.4 & 2.2 & 0.30 & 4.1 & 1.5 & 0.41 & 0.06 \\
\hline Indifferent & Lycium ferocissimum & & 38.5 & 96.2 & 12 & 64.0 & 1.0 & 0.08 & 0.9 & 0.4 & 0.14 & 0.04 \\
\hline Indifferent & Phylobolus spp. & & 52.0 & 94.3 & 28 & 56.0 & 0.8 & 0.14 & 1.2 & 0.8 & 0.24 & 0.09 \\
\hline Indifferent & Rhigozum obovatum & & 31.1 & 95.9 & 27 & 54.3 & 0.6 & 0.14 & 0.9 & 0.8 & 0.12 & 0.05 \\
\hline Preferred & Azima tetracantha & & 41.2 & 85.1 & 44 & 35.0 & 1.3 & 0.10 & 1.8 & 2.4 & 0.28 & 0.20 \\
\hline Preferred & Coddia rudis & & 46.5 & 92.8 & 44 & 39.7 & 0.6 & 0.08 & 1.1 & 1.2 & 0.18 & 0.05 \\
\hline Preferred & Grewia robusta & & 25.5 & 91.8 & 31 & 57.2 & 0.7 & 0.07 & 1.0 & 1.2 & 0.10 & 0.02 \\
\hline Preferred & Jatropha capensis & & 74.9 & 90.0 & 37 & 39.8 & 0.9 & 0.66 & 2.7 & 1.2 & 0.15 & 0.17 \\
\hline Preferred & Plumbago auriculata & & 27.4 & 95.2 & 16 & 53.0 & 1.0 & 0.07 & 1.3 & 0.4 & 0.15 & 0.07 \\
\hline Rejected & Ehretia rigida & & 54.9 & 91.9 & 28 & 45.6 & 1.4 & 0.09 & 1.6 & 1.3 & 0.25 & 0.05 \\
\hline Rejected & Phyllanthus verrucosus & & 37.0 & 95.6 & 28 & 53.9 & 0.8 & 0.12 & 0.8 & 0.8 & 0.16 & 0.05 \\
\hline Rejected & Portulacaria afra & & 73.9 & 89.5 & 33 & 46.8 & 0.5 & 0.08 & 1.9 & 0.9 & 0.71 & 0.32 \\
\hline Rejected & Ptearoxylon obliquum & & 45.2 & 94.0 & 43 & 45.4 & 1.2 & 0.13 & 0.7 & 1.4 & 0.15 & 0.02 \\
\hline Indifferent & mean & & 46.7 & 93.4 & 35 & 49.2 & 1.1 & 0.18 & 1.6 & 1.1 & 0.25 & 0.09 \\
\hline Preferred & mean & & 43.1 & 91.0 & 34 & 44.9 & 0.9 & 0.20 & 1.6 & 1.3 & 0.17 & 0.10 \\
\hline Rejected & mean & & 52.0 & 93.0 & 35 & 48.7 & 0.8 & 0.11 & 1.1 & 1.0 & 0.34 & 0.13 \\
\hline
\end{tabular}

T/L ratio twig/leaf ratio, \%water water content: (fresh-dry weight)/fresh weight, $\% O M$ organic matter content, $\%$ dig $\%$ digestibility, $\% N D F$ fibre content, $\% N$ nitrogen content, $\% P$ phosphorus content, $\% \mathrm{~K}$ potassium content, $\% \mathrm{Ca}$ calcium content, $\% \mathrm{Mg}$ magnesium content, n.a. not available 


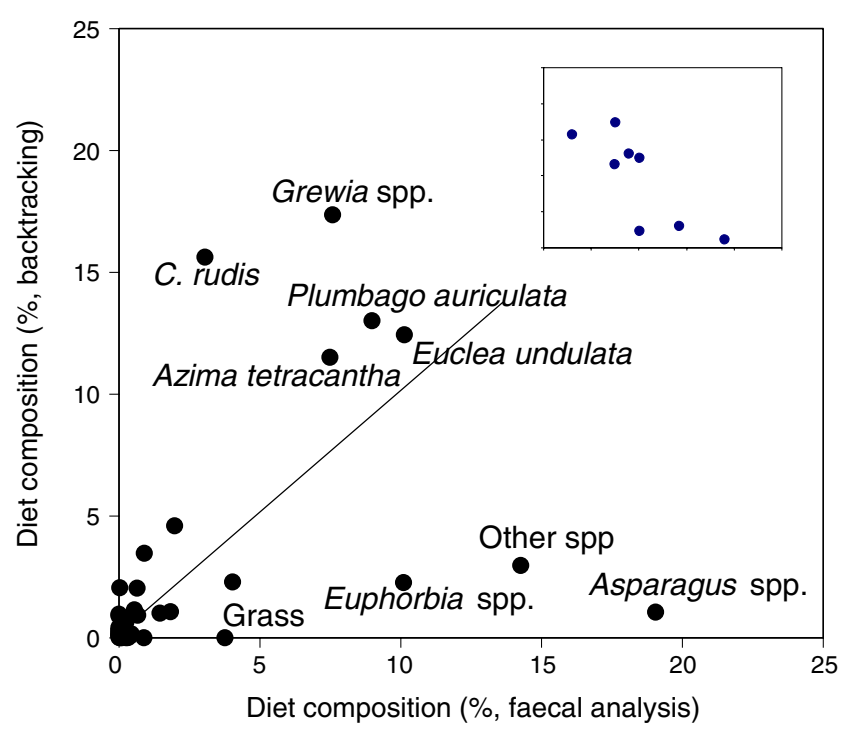

Fig. 3 Comparison of the diet composition (\%) of the black rhino in the Great Fish River Reserve in 2004, as calculated from backtracking data and faecal analysis. The straight line depicts the expected 1:1 relationship. Inset similar figure but omitting the species that have a contribution $<5 \%$ in both methods

in preference for the succulent, $E$. bothae, during the wet season, similar to the findings reported in Ganqa et al. (2005). Seasonal differences in plant species eaten by black rhinoceros were also found by Oloo et al. (1994) in the Ol Ari Nyiro Ranch, Laikipia District, Kenya who studied the diet in a wet and a dry period. This difference is perhaps due to a difference in sample sizes (backtracks) but could also be explained by annual variations in weather conditions, as Brown et al. (2003) indicated that some annuals and succulents, for example Mesembryanthemum (Phylobolus) spp., may well be seasonally more important than is generally recognised. Oloo et al. (1994) found that herbaceous species (including some semi-woody herbs) accounted for $18 \%$ of the bites in the wet period, but only $10 \%$ in the dry period. All this suggests seasonal patterns in dietary uptake in black rhino.

Diet composition: backtracking and faecal analysis

Backtracking is a method that has been used frequently by black rhino researchers, but is it reliable? In our study, we compared backtracking to faecal analysis, with the faecal analysis as the standard for the comparison. In our study, we found major differences between the importance of species in the diet as assessed by the faecal analysis and the backtracking technique (Fig. 2): Compared to faecal analyses, C. rudis and Grewia spp. are overestimated in the backtracking, whereas Asparagus spp., Euphorbia spp. and grasses are underestimated. The underestimation of grasses in the diet from backtracking data was also reported by Hall-Martin et al. (1982). Backtrack or observational studies (Joubert and Eloff 1971; Mukinya 1977; Oloo et al. 1994; Pole 1995; Muya and Oguge 2000; Winkel 2004) all reported a very low proportion of grass in the diet $(<1 \%)$ or detected no grasses at all. Therefore, one important bias in the backtracking study might be that certain bites are missed (e.g. grasses), whereas for faecal analysis, some species might not be identified to species level. Faecal samples do not exactly mirror the diet composition in the vegetation types where they are found because of the movement of herbivores and the retention time for digesting the plant material (Anthony and Smith 1974; Prins et al. 2006; Clauss et al. 2005); this might also have influenced the results. Parker and Bernard (2006) concluded that direct observations tend to overestimate important food items, but faecal analysis integrates information over time and is therefore a more conservative and potentially accurate method. Oloo et al. (1994) asserted that black rhino do not eat many annuals or herbs. However, it is likely that the presence of these plants in the diet is cryptic, with rhinos often eating entire plants, leaving no evidence behind, as Brown et al. (2003) concluded. In our study, grasses comprised $4.5 \%$ of the diet in the faecal analysis, but grasses were not detected during the backtracking. Mabinya et al. (2002), also working in GFRR, used a chemical analysis of dung analysis and reported a roughly similar proportion of grasses in black rhino diets from GFRR. HallMartin et al. (1982) also found that overall, the diet of black rhinos in Addo Elephant National Park comprised 2-10\% grass using faecal analysis, and similar values are reported for the Kruger National Park in a carbon isotope study (Codron et al. 2007). Hence, the failure of backtracking to detect grass consumption and the underestimation of herbs is an important shortcoming of the method.

Various authors suggested that the method of microhistological analyses of faeces has limitations to determine ungulate diet compositions, as differential digestion may result in differences between what is ingested and what is excreted (Leslie et al. 1983; Mukhtar and Hansen 1983; Barker 1986). Shorter ingesta retention times and slow plant fermentation rates such as for grasses (Clauss et al. 2005; Hummel et al. 2006) might create a bias in the estimation of the diet composition. No correction for digestibility, however, was necessary as plant cuticle, which is used in this study for plant identification, is indigestible in any animal's guts (Stace 1965). Digestibility of plant parts as such therefore bears no relation to recognition of cuticle or epidermis fragments.

Diet and food quality

We found no significant differences between preferred and rejected species for browse quality in terms of twig/leaf 
ratio, water content, digestibility, NDF, N, P, K, Ca, Mg, Na and crude protein. Similarly, no correlation could be found between intake of a certain species and any of the quality parameters. This absence of any correlation is in contradiction to our expectations and in contrast with the findings of Ganqa et al. (2005) who reported that crude protein was positively correlated with degree of preference among five woody species. However, Ausland et al. (2002) reported similar results to ours in terms of intake and NDF or crude protein concentrations. Similarly, Winkel (2004), working in two vegetation types in the Doubledrift sector of the GFRR, found no significant correlations between diet quality and preference indices either, which is line with the results of studies carried out in different areas (Joubert and Eloff 1971; Atkinson 1995). The marked difference between our findings and also those of Ausland et al. (2002) and Winkel (2004) with the results of Ganqa et al. (2005) cannot fully be explained at present. However, large differences occurred between the studies in the measures of species availability and thus in measures of dietary preference. For example, Ganqa et al. (2005) stated that A. karroo was the most abundant species in the study area; their data indicate it was almost twice as abundant as any other species. In contrast, $A$. karroo did not rank among the ten most abundant species in any of the three major vegetation types (short Euphorbia thicket, medium Portulacaria thicket, and tall Euphorbia thicket) we examined. Further, two species (Diospyros lycioides and Maytenus polyacantha) of the five on which they based their nutritional analyses did not even appear among our 17 principal species.

Our study indicates that black rhino in GFRR do not maximise intake of valuable nutrients, such as $\mathrm{N}$ or $\mathrm{P}$, in their diet, or minimise fibre intake. Nor do they maximise water content, as suggested by Goddard (1968) and HallMartin et al. (1982). Two explanations are available for the absence of a correlation between diet composition and forage quality. Firstly, forage quality was good overall, with a mean crude protein concentration for leaves of the principal forage species of 15.8 , well above the minimum required concentration of 7\% (Owen-Smith and Novellie 1982; Prins 1996; Hadjigeorgiou et al. 2003). The concentration of the other macro-elements $(\mathrm{P}, \mathrm{K}, \mathrm{Ca}, \mathrm{Mg}$ and $\mathrm{Na}$ ) are also well above maintenance requirements for cattle (Bokdam and Wallis de Vries 1992) and fit the suggested maintenance requirements for horses for $\mathrm{P}, \mathrm{Na}$ and $\mathrm{Mg}$, but are slightly below requirements for $\mathrm{Ca}(0.4-0.5 \%)$ and $\mathrm{K}$ (0.3-0.6\%; National Research Council 1989; Meyer and Coenen 2002). The diet quality is similar to what has been reported elsewhere for black rhino diet $(0.05-0.26 \% \mathrm{P}$, $1.8 \% \mathrm{Ca}, 0.1 \% \mathrm{Na}, 0.3-2.0 \% \mathrm{~K}, 0.1-0.9 \% \mathrm{Mg}$; Dierenfeld 1995; Dierenfeld et al. 1995; Clauss et al. 2007b). Large bulkfeeders like the black rhino are expected to be able to tolerate low-quality forage (Bell 1982). Hence, selection for high-quality forage species might not be a high priority at present for the rhino in GFRR. Secondly, the satiety hypothesis (Alm et al. 2001; Bailey and Provenza 2004) may offer an alternative explanation for the absence of a difference in quality for preferred and rejected species. Bailey and Provenza (2004) investigated the satiety hypothesis, which attributes changes in palatability to transient food aversions due to flavours, nutrients and toxins. Aversion in the diet is expected to occur when a certain point of satiety is reached when feeding on a particular plant species or in a particular feeding station (e.g. by too high levels of plant-specific secondary compounds), stimulating the consumer to switch between forage species or feeding stations. Secondary metabolite content (e.g. polyphenols or condensed tannins) might also be important, as Muya and Oguge (2000) found a negative correlation between phenol and alkaloid content and rhino utilisation, although Loutit et al. (1987) could not find any effect of soluble tannins on plant preference. Therefore, before further conclusions can be drawn, browse species should be analysed for their plant secondary metabolite content and, additionally, acid detergent fibre and lignin so that the role of plant secondary compounds on the diet choice of black rhino can be investigated (Bryant and Kuropat 1980; Cooper and Owen-Smith 1985; Clauss et al. 2007a).

It should be noted that we only analysed diet composition and browse quality of those species that were consumed by rhino to a certain degree and that we cannot draw any conclusions about those species that were totally rejected and were never recorded in the diet.

Using the correlation between twig diameter and forage biomass, the diet composition in terms of biomass per plant can be reconstructed from backtracking data. Backtracking and faecal analysis used to quantify the diet of black rhino in the GFRR yielded dissimilar results; the failure of the backtracking technique to detect grass consumption is an important one. Rhino diet composition, in terms of the difference in relative abundance of those species that comprised the majority of the diet, could not be explained by differences in forage quality parameters, and further research is therefore required in order to be able to understand the factors that govern rhino diet composition.

Acknowledgements Our special thanks goes to B. Fike, Eastern Cape Parks Board and his rangers, especially William, Nelson and Johannes who helped us a lot during our fieldwork. We are grateful to the University of Fort Hare for use of equipment. Finally, we want to thank Richard Verweij and Jan van Walsem for their help during the lab work and M. Clauss and two anonymous reviewers for their constructive comments on earlier drafts. 
Open Access This article is distributed under the terms of the Creative Commons Attribution Noncommercial License which permits any noncommercial use, distribution, and reproduction in any medium, provided the original author(s) and source are credited.

\section{References}

Alipayo D, Valez R, Holecher JL, Cardenas M (1992) Evaluation of microhistological analysis for determining ruminant diet botanical composition. J Range Manag 45:148-152. doi:10.2307/ 4002773

Alm U, Birgersson B, Leimar O (2001) The effect of food quality and relative abundance on food choice in fallow deer. Anim Behav 64:439-445. doi:10.1006/anbe.2002.3057

Anthony RG, Smith NS (1974) Comparison of rumen and fecal analysis to describe deer diets. J Wildl Manage 38:535-540. doi: $10.2307 / 3800886$

Atkinson SJ (1995) Maintenance of captive black rhinoceros (Diceros bicornis) on indigenous browse in Zimbabwe: energetics, nutrition and implications for conservation. MSc thesis, Department of Biological Sciences, University of Zimbabwe, Harare

Ausland C, Sveipe A (2000) Foraging behaviour of black rhino (Diceros bicornis minor) in the Great Fish River Reserve of the Eastern Cape, South Africa. MSc thesis, Department of Animal Science, Agricultural University of Norway, Ås, Norway

Ausland C, Sveipe A, Ganqa NM, Raats JG, Palmer AR (2002) Foraging behaviour of black rhino in the Great Fish River Reserve, Eastern Cape Province, South Africa. Proceedings of the Fifth International Wildlife Ranching Conference, Pretoria 2001. South African Game Ranchers Organisation, Pretoria

Bailey DW, Provenza FD (2004) Mechanisms determining herbivore distribution. Northern Agricultural Research Center, Montana State University, Havre, Montana USA and Department of Range, Forest and Wildlife Science, Utah State University, Logan

Barker RD (1986) An investigation into the accuracy of herbivore diet analysis. Aust Wildl Res 13:559-568. doi:10.1071/WR9860 559

Bartolome J, Franch J, Gutman M, Seligman NG (1995) Physical factors that influence fecal analysis estimates of herbivore diets. J Range Manag 48:267-270. doi:10.2307/4002432

Bell RHV (1982) The effect of soil nutrient availability on the community structure in African ecosystems. In: Huntley BJ, Walker BH (eds) Ecology of tropical savannas. Springer, Berlin, pp 193-216

Belovski GE (1997) Optimal foraging and community structure: the allometry of herbivore food selection and competition. Evol Ecol 11:641-672. doi:10.1023/A:1018430201230

Bokdam J, Wallis de Vries MF (1992) Forage quality as a limiting factor for grazing cattle in isolated Dutch nature reserves. Conserv Biol 6:399-408. doi:10.1046/j.1523-1739.1992.06030399.x

Bradstreet B (1954) Kjeldahl method for organic nitrogen. Anal Chem 26:185-187. doi:10.1021/ac60085a028

Brown DH, Lent PC, Trollope WSW, Palmer AR (2003) Browse selection of black rhinoceros (Diceros bicornis) in two vegetation types of the eastern Cape Province, South Africa, with particular reference to Euphorbiaceae. Proceedings of the VIIth International Rangeland Congress, pp 508-512

Bryant JP, Kuropat PJ (1980) Selection of winter forage by subarctic browsing vertebrates: the role of plant chemistry. Annu Rev Ecol Syst 11:261-285. doi:10.1146/annurev.es.11.110180.001401

Cid MS, Brizuela MA (1990) Grass blade and sheath quantification by microhistological analysis. J Wildl Manage 54:349-352. doi: $10.2307 / 3809053$
Clauss M, Froeschle T, Castell J, Hummel J, Hatt JM, Ortmann S, Streich WJ (2005) Fluid and particle retention times in the black rhinoceros (Diceros bicornis), a large hindgut-fermenting browser. Acta Theriol (Warsz) 50:367-376

Clauss M, Castell JC, Kienzle E, Dierenfeld ES, Flach EJ, Behlert O, Ortmann S, Streich WJ, Hummel J, Hatt JM (2006) Digestion coefficients achieved by the black rhinoceros (Diceros bicornis), a large browsing hindgut fermenter. J Anim Physiol Anim Nutr (Berl) 90:325-334. doi:10.1111/j.1439-0396.2006.00606.x

Clauss M, Castell JC, Kienzle E, Dierenfeld ES, Flach EJ, Behlert O, Ortmann S, Streich WJ, Hummel J, Hatt JM (2007a) The influence of dietary tannin supplementation on digestive performance in captive black rhinoceros (Diceros bicornis). J Anim Physiol Anim Nutr (Berl) 91:449-458. doi:10.1111/j.1439-0396.2006.00673.x

Clauss M, Castell JC, Kienzle E, Schramel P, Dierenfeld ES, Flach EJ, Behlert O, Streich WJ, Hummel J, Hatt J-M (2007b) Mineral absorption in the black rhinoceros (Diceros bicornis) as compared with the domestic horse. J Anim Physiol Anim Nutr (Berl) 91:193-204. doi:10.1111/j.1439-0396.2007.00692.x

Codron D, Codron J, Lee-Thorp JA, Sponheimer M, De Ruiter D, Sealy J, Grant R, Fourie N (2007) Diets of savanna ungulates from stable carbon isotope composition of faeces. J Zool (Lond) 273:21-29. doi:10.1111/j.1469-7998.2007.00292.x

Cooper SM, Owen-Smith N (1985) Condensed tannins deter feeding by browsing ruminants in a South African savanna. Oecologia 67:142-146. doi:10.1007/BF00378466

Cooper SM, Owen-Smith N, Bryant JP (1988) Foliage acceptability to browsing ruminants in relation to seasonal changes in the leaf chemistry of woody plants in a South African savanna. Oecologia 75:336-342. doi:10.1007/BF00376934

Cowling RM, Proches S, Vlok JHJ (2005) On the origin of southern African subtropical thicket vegetation. S Afr J Bot 71:1-23

De Boer WF, Ntumi CP, Correia AU, Mafuca JM (2000) Diet and distribution of elephant in the Maputo Elephant Reserve, Mozambique. Afr J Ecol 38:188-201. doi:10.1046/j.13652028.2000.00243.x

De Jong CB, Gill RMA, Van Wieren SE, Burlton FWE (1995) Diet selection in Kielder Forest by roe deer Capreolus capreolus in relation to plant cover. For Ecol Manage 79:91-97. doi:10.1016/ 0378-1127(95)03622-9

De Jong CB, Van Wieren SE, Gill RMA, Munro R (2004) Relationship between diet and liver carcinomas in roe deer in Kielder Forest and Galloway Forest. Vet Rec 155:197-200

Dierenfeld ES (1995) Rhinoceros nutrition: an overview with special reference to browsers. Verh Erkrg Zootiere 37:7-14

Dierenfeld ES, du Toit R, Braselton WE (1995) Nutrient composition of selected browses consumed by black rhinoceros (Diceros bicornis) in the Zambezi Valley, Zimbabwe. J Zoo Wildl Med 26:220-230

Emslie RH, Adcock K (1994) Feeding ecology of black rhinoceros. In: Penzhorn BL, Kriek NPJ (eds) Proceedings of the symposium Rhinos as game ranch animals. SAVA Wildlife Group, Onderstepoort, pp 65-81

Evans NV, Avis AM, Palmer AR (1997) Changes to the vegetation of the mid-Fish River valley, Eastern Cape, South Africa. Afr J Range For Sci 14:68-74

Ewing GW (1997) Analytical instrumentation handbook. Marcel Dekker, New York

Ganqa NM, Scogings PF (2007) Forage quality, twig diameter, and growth habit of woody plants browsed by black rhinoceros in semi-arid subtropical thicket, South Africa. J Arid Environ 70:514-526. doi:10.1016/j.jaridenv.2007.02.003

Ganqa NM, Scogings PF, Raats JG (2005) Diet selection and forage quality factors affecting woody plant selection by black rhinoceros in the Great Fish River Reserve, South Africa. S Afr J Wildl Res 35:77-83 
Goddard J (1968) Food preferences of two black rhinoceros populations. East Afr Wildl J6:1-18

Hadjigeorgiou IE, Gordon IJ, Milne JA (2003) Comparative preference by sheep and goats for Graminaeae forages varying in chemical composition. Small Rumin Res 49:147-156. doi:10.1016/S0921-4488(03) 00094-4

Hall-Martin AJ, Erasmus T, Botha BP (1982) Seasonal variation of diet and faeces composition of Black rhinoceros Diceros bicornis in the Addo Elephant National park. Koedoe 25:63-82

Heilmann LC, de Jong K, Lent PC, de Boer WF (2006) Will tree euphorbias (Euphorbia tetragona and Euphorbia triangularis) survive under the impact of black rhinoceros (Bicornis diceros minor) browsing in the Great Fish River Reserve, South Africa? Afr J Ecol 44:87-94. doi:10.1111/j.1365-2028.2006.00620.x

Homolka M, Heroldová M (1992) Similarity of the results of stomach and faecal contents analyses in studies of the ungulate diet. Folia Zool (Brno) 41:193-208

Hummel J, Südekum KH, Streich WJ, Clauss M (2006) Forage fermentation patterns and their implications for herbivore ingesta retention times. Funct Ecol 20:989-1002. doi:10.1111/j.13652435.2006.01206.x

Joubert E, Eloff FC (1971) Notes on the ecology and behaviour of the black rhino in South West Africa. Madoqua 1:5-53

Lacher TE Jr, Willig MR, Mares MA (1981) Food preference as a function of resource abundance with multiple prey types: an experimental analysis of optimal foraging theory. Am Nat 120:297-316. doi:10.1086/283992

Lent PC, Fike B (2003) Home ranges, movements and spatial relationships in an expanding population of black rhinoceros (Diceros bicornis minor) in the Great Fish River Reserve, South Africa. S Afr J Wildl Res 33:109-118

Leslie DM, Vavra M, Starkey EE, Slater RC (1983) Correcting for differential digestibility in microhistological analyses involving common coastal forages of the Pacific Northwest. J Range Manag 36:730-732. doi:10.2307/3898197

Loutit BD, Louw GN, Seely MK (1987) First approximation of food preferences and the chemical composition of the diet of the desertdwelling black rhinoceros (Diceros bicornis). Madoqua 15:35-54

Mabinya LV, Brand JM, Raats JG, Trollope WSW (2002) Estimation of grazing by herbivores from analysis of dung. Afr J Range Forage Sci 19:175-176

Maddock AH, la Cock GD, Burger M (1995) Feeding trials on captive black rhinoceros Diceros bicornis minor in the Eastern Cape, South Africa. S Afr J Sci 25:32-34

Martin DJ (1955) Features on plant cuticle; an aid to the analysis of the natural diet of grazing animals, with special reference to Scottish hill sheep. Bot Soc Edindurgh Trans 36:378-388

Meyer H, Coenen M (2002) Pferdefütterung. Parey, Berlin

Mukhtar HK, Hansen RM (1983) Fiber effects on microhistological analysis. J Range Manag 36:477-478. doi:10.2307/3897945

Mukinya JG (1977) Feeding and drinking habits of the black rhinoceros in Masai Mara Game Reserve. East Afr Wildl J 15:125-138

Muya SM, Oguge NO (2000) Effects of browse availability and quality on black rhinoceros (Diceros bicornis michaeli Groves
1967) diet in Nairobi National Park, Kenya. Afr J Ecol 38:62-71. doi:10.1046/j.1365-2028.2000.00213.x

National Research Council (1989) Nutrient requirements of horses. National Academy Press, Washington, DC

Oloo TW, Brett R, Young TP (1994) Seasonal variation in the feeding ecology of black rhinoceros (Diceros bicornis L.) in Laikipia, Kenya. Afr J Ecol 32:142-157. doi:10.1111/j.1365-2028.1994. tb00565

Owen-Smith N, Novellie P (1982) What should a clever ungulate eat. Am Nat 119:151-178. doi:10.1086/283902

Parker DM, Bernard RTF (2006) A comparison of two diet analysis techniques for a browsing megaherbivore. J Wildlife Manage 70:1477-1480

Pole A (1995) Feeding ecology of semi-intensive black rhinoceros (Diceros bicornis) in a highveld habitat. Doctoral thesis (biology), University of Zimbabwe, Zimbabwe

Prins HHT (1996) Ecology and behaviour of the African buffalo. Social inequality and decision making. Chapman and Hall, London

Prins HHT, de Boer WF, van Oeveren H, Correia A, Mafuca J, Olff H (2006) Co-existence and niche segregation of three small bovid species in southern Mozambique. Afr J Ecol 44:186-198. doi:10.1111/j.1365-2028.2006.00619.x

Putman RJ (1984) Facts from faeces. Mamm Rev 14:79-97. doi:10.1111/j.1365-2907.1984.tb00341.x

Schenkel R, Schenkel-Hullinger L (1969) Ecology and behaviour of the black rhinoceros (Diceros bicornis L.). Paul Parey, Hamburg, Berlin

Siegel S, Castellan NJ (1988) Nonparametric statistics for the behavioral sciences. McGraw-Hill, New York

Sparks DR, Malechek C (1968) Estimating percentage dry weight in diets using a microscopic technique. J Range Manag 21:264-265. doi: $10.2307 / 3895829$

Stace CA (1965) Cuticular studies as an aid to plant taxonomy. Bull Br Mus Nat. Hist., Bot 4:1-78

Stewart DRM (1967) Analysis of plant epidermis in faeces:a technique for studying the food preferences of grazing herbivores. J Appl Ecol 4:83-111. doi:10.2307/2401411

Tilly JMA, Terry RA (1963) A two-stage technique for the in vitro digestion of forage crops. J Br Grassl Soc 18:104-111

Udén P, Robinson P, Wiseman J (2005) Use of detergent system terminology and criteria for submission of manuscripts on new, or revised, analytical methods as well as descriptive information on feed analysis and/or variability. Anim Feed Sci Technol 118:181-186. doi:10.1016/j.anifeedsci.2004.11.011

Wilson SL, Kerley GIH (2003) Bite diameter selection by thicket browsers: the effect of body size and plant morphology on forage intake and quality. For Ecol Manage 181:51-65. doi:10.1016/ S0378-1127(03) 00114-2

Winkel F (2004) Diet choice of the black rhinoceros (Diceros bicornis) in the Doubledrift Game Reserve, Eastern Cape Province, South Africa. MSc thesis, Wageningen University, Wageningen

Zar JH (1984) Biostatistical analysis, 2nd edn. Prentice Hall, Englewood Cliffs 